\title{
Margaret McCartney: Nagging people is a futile exercise
}

\author{
Margaret McCartney general practitioner, Glasgow
}

We're bossy and boring. Do more exercise! Take the stairs! Have you done your 30 minutes today? Exercise is promoted as a moral good, something to which responsible citizens should be enslaved, or at least devoted.

We are all urged to exercise regularly to save the NHS money in the long term, to stop us getting fat, getting diabetes, Alzheimer's disease, depression - and from infarcting our myocardiums. We are repeatedly told of a host of diseases that we might experience if we dare not clothe ourselves in Lycra and step up to the treadmill. In short, we are oppressed by medical do-gooders, nagging us to do more and guilt tripping us into going to the gym.

Doctors are not immune to this pressure. Cardiologists at a 2013 conference who dared to use an escalator rather than the stairs had their photographs shared on Twitter with disdain (http://bit. ly/1EBXAtD); in their defence, they probably had massive suitcases.

But, just as in general elections, the public doesn't like a negative campaign. Asking us to do something hard now for a possible absence of diabetes in 20 years is a prime example. The medical establishment should not be in charge of promoting exercise, because we come across as stool gazing, risk averse killjoys, pointing fingers joylessly from a lectern.

Nagging people about the need to do exercise to achieve health won't work. Exercise should be for the people, by the people. It should be about good living-less "good for you" and more "feel good." To run and work up a sweat results in a satisfying leg tingle for the rest of the day; the roaring pleasure of downhill on a bike is worth the thigh burn on the uphill. The truth is that post-exercise glow is on the orgasmic spectrum. And Zumba dance classes encourage friendships, just as walking groups create networks. Medicine should agitate to create a society in which exercise is the easy, pleasant option; we should quit nagging and start enabling.

Until people perceive it as safer to send their kids to school by bike or on foot rather than to drive them, we have failed. Children should be allowed to make the street they live in their playground (see the fantastic Playing Out project: http:// playingout.net). We need streets designed for play and active travel. We need cities that love cycling and encourage rather than merely tolerate it, and local authorities should think imaginatively about how to offer affordable opportunities to people who lack the confidence or the means to join in.

It's not patients that doctors should be nagging—it's policy makers.

Competing interests: I have read and understood the BMJ policy on declaration of interests and declare the following interests: I'm an NHS GP partner, with income partly dependent on Quality and Outcomes Framework points. I'm a part time undergraduate tutor at the University of Glasgow. I've written two books and earn from broadcast and written freelance journalism. I'm an unpaid patron of Healthwatch. I make a monthly donation to Keep Our NHS Public. I'm a member of Medact. I'm occasionally paid for time, travel, and accommodation to give talks or have locum fees paid to allow me to give talks but never for any drug or public relations company. I was elected to the national council of the Royal College of General Practitioners in 2013 and am chair of its standing group on overdiagnosis. I have invested a small amount of money in a social enterprise, Who Made Your Pants?

Provenance and peer review: Commissioned; not externally peer reviewed.

Follow Margaret on Twitter, @mgtmccartney

Cite this as: BMJ 2015:351:h4515

๑ BMJ Publishing Group Ltd 2015 